\title{
FISCAL DECENTRALIZATION AND ITS IMPACT ON DEVELOPMENT OF PROPERTY TAXES IN THE SLOVAK REPUBLIC
}

\author{
[Fiškálna decentralizácia a jej vplyv na vývoj dane z nehnutel’nosti v Slovenskej \\ republike]
}

Erik Poláček ${ }^{1}$

${ }^{1}$ Slezská univerzita, Obchodně podnikatelská fakulta, Univerzitní nám. 1934/3,733 40 Karviná Email:polacek_erik@opf.slu.cz

\begin{abstract}
Fiscal decentralization as a tool for the transfer of competences from the central level of government to lower levels of government - municipalities and higher territorial units. The introduction of fiscal decentralization in Slovakia, a new method of funding, which has the effect of reinforcing the financial autonomy of these entities, their stability, independence and effectiveness in the use of funds to implement their plans for investments to meet the needs of residents of municipalities and actual and potential businesses engaged in business activities the territory of the municipality.
\end{abstract}

Keywords: financial autonomy, fiscal decentralization, municipalities, property tax.

JEL classification: H71

Doručeno redakci: 9.2.2017; Recenzováno: 21.2.2017; 19.3.2017; 12.4.2017; Schváleno k publikování: 20.9.2017

\section{Úvod}

Teória fiškálnej decentralizácie prešla istým vývojom, ktorý sumarizuje autor Porceli (2009) a podobne aj autori Dziobek et al (2011) vo svojich publikáciách v dvoch etapách. Prvá etapa, reprezentovaná názormi klasických autorov ako Samuelson, Musgrave a Arrow, dospela $\mathrm{k}$ názoru, že pre centrálnu úroveň je najlepšie, aby prebrala na seba úlohy v oblasti makroekonomickej stabilizačnej politiky a zabezpečovala verejné statky národného významu. Miestna samospráva by kvôli znalosti miestnych podmienok mala mat' zverené zabezpečovanie lokálnych verejných statkov, s istým dohl'adom národnej vlády pre prípad vzniku nežiaducich nerovností. Prvá generácia autorov sa venovala tiež vhodnosti daňového určenia a dospela k názoru, že miestne vlády by mali mat' v rukách najmä daň z nehnutel'ností a užívatel'ské poplatky tak, aby nebol možný l'ahký prenos daňového základu. Weingast, McKinnom a d’alší, druhá generácia teórie fiškálnej decentralizácie obohatila skúmanie fiškálnej decentralizácie o d’alšie dôležité témy, najmä z politickej vedy a ekonómie. Klúčovými otázkami v spojitosti s teóriou fiškálneho federalizmu sa stali morálny hazard, spôsob poskytovania informácií, problém asymetrických informácií, vzt’ahy medzi jednotlivými úrovňami verejnej vlády a podobne. U druhej generácii prevládal názor, že financovanie prostredníctvom vlastných miestnych zdrojov je účinnejšie než prostredníctvom transferov z prerozdel'ovacích procesov. Tieto teoretické konštrukcie sa vel'mi výrazne využívajú pri kreovaní konkrétnych modelov fiškálnej decentralizácie v praxi Knežová (2015). Prvotne môže existovat' skutočný dopyt po decentralizácii zo strany miestnej úrovne pre miestnu demokratickú kontrolu a finančnú autonómiu, ako napríklad prišiel dopyt v strednej a východnej Európe od začiatku 90tych rokov ako reakcia na ukončenie jednej politickej a ekonomickej éry so zlyhaním centralizovaného riadenia štátov Dabla-Norris (2006) a Hollis and Plokker (1995). Podl'a Wetzel a Dunn (2001) je druhým dôvodom fiškálnej decentralizácie všeobecne uznávané, že decentralizačné výsledky ukazujú na rast prosperity obcí či iných územných celkov. V podstate sa má za to, že miestne potreby 
a preferencie verejných služieb možno najlepšie dosiahnut' tým, že rozhoduje lokálna a nie ústredná vláda. Tretím dôvodom je, že prenesenie týchto kompetencií na nižšiu úroveň vlády zmierňuje tlak na štátny rozpočet, tento trend je výsledkom prevodu finančnej zodpovednosti z ústredných orgánov na nižšie orgány vlády a tým sú nútené poskytovat' a financovat' rastúci počet služieb Swianiewicz (2003). Konečne, ako navrhol Bryson a Cornia (2000, s. 507-522), decentralizácia je videná ako neoddelitel'ná súčast' riešenia mnohých problémov, ktorým čelia prechodové krajiny, ktoré zahrňujú zvýšené nároky na verejné služby, demografické tlaky a rastúce očakávania verejnosti, pokial' ide o kvalitu služieb. Tie môžu priamo prispiet' k fiškálnym potrebám miestnych samospráv, ale neposkytujú riešenie problému týkajúceho sa fiškálneho priestoru.

Ukotvenie decentralizácie v miestnej vládnej legislatíve vo väčšine tranzitných krajinách je právo na finančnú autonómiu a administratívnu nezávislost' voči centrálnemu ovládaniu. Právo na „vlastníctvo“ vlastného daňového základu viedlo k úvahe o zavedení najvhodnejších miestnych poplatkov. Decentralizácia tak tvorí dôležitú súčast' rozvoja demokracie, ako je uvedené v Európskej charte miestnej samosprávy, ktorú prijala Rada Európy 15. októbra v roku 1985 Rada Európy (1985). Hoci sa jedná pri daniach z nehnutel'nosti o okrajový zdroj príjmov, vláda je nútená premýšl’at' o tomto príjme počas nepriaznivej ekonomickej situácie. Možné zmeny vedúce $\mathrm{k}$ zvýšeniu v ich príjmoch, sú brané do úvahy. Najmä problematika oceňovania majetku je určená $\mathrm{v}$ rámci teoretických prístupov a empirických štúdií, ked' ich hodnota predstavuje vstup pre stanovenie základu dane $\mathrm{z}$ nehnutel'ného majetku Horne a Felsensteinem (2010) a Presbitero et al. (2014). Daňové príjmy z dane z nehnutel'ností ako finančný príjem do obecného rozpočtu nie je vel'mi významný. Podl'a Radvaňa (2007), boli klesajúce od začiatku 20. storočia $\mathrm{v}$ prospech výnosnejších nepriamych daní alebo tých $\mathrm{z}$ príjmu. Je viac než zrejmé, že existujú rozpory v prístupe $\mathrm{k}$ dani $\mathrm{z}$ nehnutel'ností $\mathrm{v}$ dnešnej dobe. Jedna čast' podporuje názor, že daň z nehnutel'ností je skôr zát'ažou z dôvodu ich podielovo málo významného inkasa do obecného rozpočtu.

Na problematiku dane $\mathrm{z}$ nehnutel'nosti sa $\mathrm{v}$ konečnom dôsledku možno pozerat' $\mathrm{z}$ dvoch uhlov pohl'adu. Na strane jednej výnos dane $z$ nehnutel'nosti je podielovo v príjmoch obce zanedbatel'ným príjmom v podmienkach Slovenskej republiky, avšak tento príjem je každoročne očakávaný na pokrytie rôznych výdavkov spojených s prevádzkou verejných záujmov obce. Na strane druhej, predstavitelia obce nechcú zvyšovat' podiel dane z nehnutel'ností v obecnom rozpočte, pretože zvýšením sadzieb daní z nehnutel'ností sa zvýši rizikovo opätovného znovuzvolenia do čela obce alebo do obecného zastupitel'stva.

\section{Ciel' príspevku a metodika spracovania}

Ciel'om tohto príspevku je deskripcia a vyhodnotenie fiškálnej decentralizácie v Slovenskej republike ako nástroja pre zvýšenie finančnej autonómie slovenských obcí prostredníctvom dane z nehnutel'ností pri rozhodovaní o ich investičných krokoch v kontexte uspokojovania potrieb občanov. Zámerom príspevku je vyhodnotenie sekundárnych štatistických údajov získaných z Ministerstva financií Slovenskej republiky a mesta Čadca za obdobie 2006 2015, taktiež spracovanie súhrnu teoretických východísk tuzemských i zahraničných autorov zaoberajúcich sa danou problematikou. Metódou dopytovania získanie primárnych štatistických údajov, ich následné vyhodnotenie.

$\mathrm{V}$ rámci metodiky spracovania príspevku je vo výsledku niekol'ko úloh - deskripcia, vyhodnotenie, rešerš literatúry a aplikácia v podmienkach Slovenskej republiky. 


\section{Decentralizačné procesy v Slovenskej republike}

November 1989 predstavoval v Slovenskej republike nielen odštartovanie celospoločenských zmien, ale taktiež sa inicioval proces reformy verejnej správy, dochádzalo $\mathrm{k}$ návratu spoločnosti do pôvodného, prirodzeného stavu.

Tabul'ka 1: Plánovaný proces decentralizácie

\begin{tabular}{|c|c|c|}
\hline Obdobie & Inštitúcia & Kompetencie \\
\hline do $06 / 1990$ & - Ministerstvo vnútra SR & $\begin{array}{l}\text { - Posúdenie a vypracovanie nového modelu } \\
\text { a štruktúry miestnych orgánov verejnej } \\
\text { správy. }\end{array}$ \\
\hline $\begin{array}{l}06 / 1990- \\
06 / 0992\end{array}$ & $\begin{array}{l}\text { - } 3 \text { expertné pracovné skupiny: dve } \\
\text { vládne a jedna menovaná SNR. } \\
\text { komisia vlády pre riešenie verejnej } \\
\text { správy a územnosprávneho členenia }\end{array}$ & $\begin{array}{l}\text { - Návrh nového územného členenia } \\
\text { a optimálneho modelu verejnej správy. } \\
\text { - Posúdenie výstupov práce expertných } \\
\text { skupín a návrh najvhodnejšieho variantu. }\end{array}$ \\
\hline $\begin{array}{l}06 / 1992- \\
02 / 1995\end{array}$ & $\begin{array}{l}\text { - Komisia vlády na čele s podpredsedom } \\
\text { vlády, s prizvaním odborníkov z MVO }\end{array}$ & $\begin{array}{l}\text { Vypracovanie a predloženie správy } \\
\text { o postupe prác na koncepcii miestnej } \\
\text { verejnej správy. Predkladanie štvrt’ročných } \\
\text { správ }\end{array}$ \\
\hline $\begin{array}{c}02 / 1995- \\
1998\end{array}$ & $\begin{array}{l}\text { - Vznik Rady vlády pre verejnú správu - } \\
\text { poradný orgán vlády Presun } \\
\text { zodpovednosti na ministerstvo vnútra }\end{array}$ & $\begin{array}{l}\text { - Stanoviská k materiálom s odporúčacím } \\
\text { charakterom pre vládu. Správa ministra o } \\
\text { postupe prác. Príprava rozhodujúcich } \\
\text { zákonov. }\end{array}$ \\
\hline $\begin{array}{l}12 / 1998- \\
08 / 2001\end{array}$ & - Ministerstvo vnútra & $\begin{array}{l}\text { - Príprava stratégie d'alšieho postupu a } \\
\text { posúdenie potreby zmeny územného } \\
\text { členenia SR. }\end{array}$ \\
\hline $\begin{array}{l}02 / 1999- \\
08 / 2001\end{array}$ & $\begin{array}{l}\text { - Splnomocnenec vlády SR pre projekt } \\
\text { reformy verejnej správy a } \\
\text { decentralizácie, od júna } 2000 \text { podliehal } \\
\text { splnomocnenec vlády podpredsedovi } \\
\text { vlády pre ekonomiku Príslušné } \\
\text { ministerstvá }\end{array}$ & $\begin{array}{l}\text { - Stratégia reformy verejnej správy. } \\
\text { Koncepcia decentralizácie a modernizácie } \\
\text { verejnej správy. Koordinácia v zmysle } \\
\text { naplnenia koncepcie (štátna správa, } \\
\text { samospráva MVO). Príprava a predkladanie } \\
\text { zákonov. }\end{array}$ \\
\hline $\begin{array}{l}09 / 2001- \\
12 / 2002\end{array}$ & - Ministerstvo vnútra & - Koordinácia a príprava zákonov. \\
\hline $\begin{array}{l}01 / 2003- \\
2006\end{array}$ & $\begin{array}{l}\text { - Splnomocnenec vlády SR v spolupráci } \\
\text { s ministrom vnútra a ministrom } \\
\text { financií Príslušné ministerstvá }\end{array}$ & $\begin{array}{l}\text { Koordinácia (štátna správa, samospráva, } \\
\text { MVO) v zmysle pôvodnej koncepcie, } \\
\text { príprava projektu decentralizácie na roky } \\
2003 \text { - 2006, príprava komunálnej reformy, } \\
\text { spolupráca S MV SR na koncepcii reformy } \\
\text { miestnej štátnej správy, s MF SR na } \\
\text { fiskálnej decentralizácii, príprava a } \\
\text { predkladanie zákonov. }\end{array}$ \\
\hline
\end{tabular}

Zdroj: Nižňanský (2013)

Ako uviedol Krivý (1996) vo svojej štúdii „Slovensko je významne regionálne diferencované“ čo bolo potrebné brat' v zretel' pri implementácii decentralizácie v podmienkach Slovenskej republiky. Decentralizácia v Slovenskej republike mala za následok vybudovanie novej kvalitnejšej základne v rámci vzt’ahov na území. S rastúcimi kompetenciami územných samospráv, rastie aj postavanie a zodpovednost' pre zabezpečenie komplexného rozvoja regiónov, v ktorých sú jednotlivé samosprávy. Slovenské samosprávne orgány sa snažia využívat' všetky dostupné nástroje, ktoré získali decentralizáciou pre urýchlenie rozvoja. Súčast'ou decentralizácie bolo nové financovanie územných samospráv obcí a vyšších územných celkov. Hlavnou podstatou bolo posilnenie finančnej autonómie, finančnej sebestačnosti. Posilnenie daňových príjmov územných samospráv, tvoriacich hlavnú čast' príjmov. Celkovo ide o prepojenie medzi hospodárením samosprávy a spoločenskými nákladmi. Pozitívne ohlasy a pozitívny dopad na financovanie územných samospráv priniesla realizáciu finančnej decentralizácie v podmienkach Slovenskej republiky. 
Uznesením vlády Slovenskej republiky č. 230 z 11.4. 2000 patrí medzi očakávané prínosy fiškálnej decentralizácie:

- priblíženie občana $\mathrm{k}$ rozhodujúcim procesom štátnej moci, teda jeho aktivizácia na verejnom živote

- výhody plynúce z miestneho posúdenia a rozhodovania pri prispôsobení služieb miestnym podmienkam

- zvýšenie efektívnosti výkonu samotnej verejnej správy

- posilnenie štátu ako celku, rozložením právomoci, ale aj zodpovednosti na všetky úrovne verejnej správy pri rešpektovaní princípu subsidiarity

- posilnenie fungovania inštitútov demokracie, posilnenie vplyvu občanov a nimi priamo volených predstavitel'ov

- väčšia transparentnost's dopadom na znižovanie miery klientelizmu a korupcie

- zvýšenie ekonomickej výkonnosti štátu a najmä regiónov

- efekty z cezhraničnej a medziregionálnej spolupráce

- zastavenie rastu regionálnych a miestnych disparít

Decentralizácia neprináša len pozitíva, ale aj riziká a medzi možné riziká vyplývajúce z decentralizácie verejnej správy Slovenskej republiky patria:

- riziko presadzovania vlastných skupinových záujmov v rámci decentralizovaných zložiek

- náročnejšie riadenie ako pri centralizovanom systéme

- náročnejšia kontrola decentralizovaného systému

- fiškálna externalita pri určovaní podoby a výšky verejných rozpočtov

Netreba zabudnút' medzinárodnú úpravu, ktorá sa priamo dotýka fiškálnej decentralizácie, Európska charta miestnej samosprávy, ktorá bola prijatá v Štrasburgu 15. októbra 1985 a Slovenská republika je touto chartou viazaná a od 1. júna 2000 vošla do platnosti pre Slovenskú republiku. Najvýznamnejším článkom z charty je článok 9 zaoberajúci sa finančnými zdrojmi miestnych orgánov.

- primerané vlastné prostriedky s vol’ným disponibilným právom

- finančné prostriedky úmerne kompetenciám

- aspoň čast' príjmov musí byt' z miestnych daní a poplatkov

- ochrana finančne sladších miestnych orgánov

- spôsob prerozdelenia zdrojov sa konzultuje s miestnymi orgánmi

- dotácie pre miestne orgány nie sú účelovo viazané

- pri získavaní úverov na kapitálové investície majú miestne orgány v medziach zákona prístup na vnútorný kapitálový trh

Pre úspešnost' a efektívnost' modelu decentralizácie je potrebná eliminácia rizík vyplývajúcich zo zavedenia decentralizácie prostredníctvom jasného rozdelenia pôsobnosti, právomocí a zodpovednosti medzi jednotlivé úrovne verejnej správy, zavedením vonkajších i vnútorných kontrolných mechanizmov a zavedením mechanizmov pre transparentnost' financovania. Vláda Slovenskej republiky schválila v roku 2000 koncepciu decentralizácie verejnej správy, d'alším rozhodnutím Národnej rady Slovenskej republiky v roku 2001 bolo rozhodnutie o územnom a správnom členení, vytvorenie vyšších územných celkov a pre úplnost' fungovania bolo potrebné aby občania Slovenskej republiky v tom istom roku prišli k volebným urnám a zvolili si predstavitel'ov, ktorí ich budú zastupovat', od roku 2002 vyššie územné celky zahájili činnost'. Schválenie fiškálnej decentralizácie v Slovenskej republike bolo v roku 2004 a tak nastal prelomový rok 2005 z dôvodu odovzdávania a presunu 
kompetencií z miestnej štátnej správy a ústredných orgánov obciam a vyšším územným celkom.

Podstatnú čast' príjmov samospráv predstavoval pred reformou príspevok od štátu. Približne $47 \%$ tvorili podielové dane ako príjmy obecných rozpočtov samospráv. Samosprávy postupne preberali vd’aka decentralizácii úlohy od štátu, čím získali do svojho vlastníctva aj majetok, ktorý bol určený na plnenie zverených pôsobností. Na prevádzkovanie majetku získaného od štátu samosprávy a vyššie územné celky získali finančné prostriedky ako účelové tzv. decentralizačné dotácie, okrem týchto dotácií samosprávy dostali od štátu i finančné prostriedky na mzdy odborných zamestnancov. Decentralizácia priniesla zásadné zmeny vo financovaní, pred rokom 2005 záviselo financovanie samospráv od pridelenia podielu daní zo štátneho rozpočtu, od roku 2005 sa prerozdel'ovanie podielu daní zmenilo v dôsledku druhej daňovej reformy na Slovenku. Podl'a zákona NR SR č. 564/2004 Z.z. je jediná centrálne prerozdel'ovaná daň pre obce daň z príjmov fyzických osôb, vo výške $70,3 \%$, pre vyššie územné celky vo výške $20,5 \%$ a pre štátny rozpočet $6,2 \%$.

Tabul'ka 2: Príjmy z dane FO

\begin{tabular}{|c|c|c|c|c|}
\hline & $\begin{array}{c}\text { Daň z príjmu FO } \\
\text { (v tis. Eur) }\end{array}$ & $\begin{array}{c}\text { Obec - 70,3\% } \\
\text { (v tis. Eur) }\end{array}$ & $\begin{array}{c}\text { VÚC -20,5\% } \\
\text { (v tis. Eur) }\end{array}$ & $\begin{array}{c}\text { Śtátny rozpočet - } \\
6,2 \% \text { (v tis. Eur) }\end{array}$ \\
\hline 2005 & 1331640 & 936143 & 272986 & 82562 \\
\hline 2006 & 1348868 & 948254 & 276518 & 83630 \\
\hline 2007 & 1546537 & 1087216 & 317040 & 95885 \\
\hline 2008 & 1827092 & 1284446 & 374554 & 113280 \\
\hline 2009 & 1639137 & 1152313 & 336023 & 101626 \\
\hline 2010 & 1467472 & 1031633 & 300832 & 90983 \\
\hline 2011 & 1686798 & 1185819 & 345794 & 104581 \\
\hline 2012 & 1833319 & 1288823 & 375830 & 113666 \\
\hline 2013 & 1851766 & 1301791 & 379612 & 114809 \\
\hline 2014 & 1971289 & 1385816 & 404114 & 122220 \\
\hline 2015 & 2162091 & 1519950 & 443229 & 134050 \\
\hline
\end{tabular}

Zdroj: Webový portál Ministerstva financií SR: Fiškálna decentralizácia [online][vid. 2.januára 2017]. Dostupné $\mathrm{z}<$ http://www.mfsr.sk/Default.aspx?CatID=3507>.

Prerozdel'ovanie dane z príjmu fyzických osôb je prerozdel'ovaná podl'a vel'kosti obce a charakteru kompetencie. Decentralizáciou vzrástla daňová sila územných samospráv, nastal rastúci trend $\mathrm{v}$ absolútnom aj relatívnom vyjadrení v príjmoch podielových daní. Spustením fiškálnej decentralizácie sú miestne dane fakultatívne a územné samosprávy sa rozhodnú či budú jednotlivé dane vyberat' na svojom území. Každá územná samospráva na území Slovenskej republiky sa môže rozhodnút' o sadzbe miestnych daní vo všeobecne záväznom nariadení.

Podstatou finančnej decentralizácie v Slovenskej republike bolo v prvom rade zníženie dotácií v podobe daňových príjmov zo strany štátu smerom k samosprávam a vyšším územným celkom, zmeny museli nastat' $\mathrm{v}$ daňovej právomoci i v daňovom určení vybraných daní. Legislatíva upravujúca rámec fiškálnej decentralizácie v podmienkach Slovenskej republiky tvoria dva zákony:

- zákon NR SR č. 564/2004 Z.z.

- zákon NR SR č. 582/2004 Z.z. 
Výnimkou bolo obdobie rokov 2002 - 2003 kedy vyššie územné celky dostávali od štátu účelové dotácie, tzv. decentralizačné dotácie, prostredníctvom ktorým vyššie územné celky financovali svoje úlohy v medziobdobí fiškálnej decentralizácie.

Zákon č. 564/2004 Z.z. upravuje rozpočtové určenie, spôsob rozdel'ovania, termíny poukazovania a poukazovanie výnosu dane z príjmov fyzických osôb do rozpočtov samospráv a vyšších územných celkov. Systém rozdel'ovania výnosu dane z príjmov fyzických osôb do rozpočtov obcí a vyšších územných celkov je upravený nariadením vlády Slovenskej republiky z 2. decembra 2004 o rozdel'ovaní výnosu dane z príjmov územnej samospráve, ktorú malo za úlohu vypracovat' Ministerstvo financií Slovenskej republiky na základe zákona č. 564/2004 Z.z., ktorý bol základom pre zákon č. 668/2004 Z.z.

Podl'a zákona č. 668/2004 Z.z. sa výnos dane z príjmov fyzických osôb rozdelí obciam takto:

- $23 \%$ podl'a počtu obyvatel'ov obce s trvalým pobytom na území danej obce, z toho $57 \%$ prepočítaný koeficientom nadmorskej výšky obce podl'a prílohy č. 1 tohto zákona

- 32\% podl'a počtu obyvatel'ov obce s trvalým pobytom na území danej obce prepočítaného koeficientom v závislosti od zaradenia obce vel'kostnej kategórie podl'a prílohy č. 2 tohto zákona

- $40 \%$ podl'a počtu žiakov

- $5 \%$ podl'a počtu obyvatel'ov obce, ktorí dovŕšili vek šest'desiatdva rokov s trvalým pobytom na území obce

Všetky náležitosti sú vždy $\mathrm{k}$ 1. januáru predchádzajúceho kalendárneho roka. Podiel obce na výnose dane sa vypočíta vždy mesačne podl'a vzorca uvedeného v prílohe č. 4 tohto zákona.

Výnos dane z príjmu fyzických osôb sa rozdel'uje vyšším územným celkom podl'a zákona č. 668/2004 Z.z. takto:

- $15 \%$ podl'a počtu obyvatel'ov vyššieho územného celku s trvalým pobytom na jeho území

- $15 \%$ podl'a počtu obyvatel'ov vyššieho územného celku vo veku pätnást' až osemnást' rokov s trvalým pobytom na jeho území

- $32 \%$ podl'a počtu obyvatel'ov vyššieho územného celku, ktorí dovíšili šest'desiatdva rokov s trvalým pobytom na území vyššieho územného celku

- $9 \%$ podl'a obrátenej hustoty obyvatel'stva vyššieho územného celku

- $20 \%$ podl'a dížky ciest II. a III. triedy vo vlastníctve vyššieho územného celku

- $9 \%$ podl'a rozlohy vyššieho územného celku

Všetky náležitosti sú vždy $\mathrm{k} 1$. januáru predchádzajúceho kalendárneho roka. Aj v tomto prípade sa podiel dane pre vyšší územný celok vypočíta mesačne podl'a vzorca $\mathrm{v}$ prílohe č. 5 tohto zákona

Zákon 582/2004 Z.z. s účinnost'ou od 1. januára 2005 upravuje, ktoré dane môžu samosprávy a vyššie územné celky vyberat' v pôsobnosti svojho katastrálneho územia. Do miestnych daní sa z pôvodných 13 miestnych poplatkov a dane $\mathrm{z}$ nehnutel'nosti vytvorilo celkovo 8 miestnych daní a 1 miestny poplatok za komunálne odpady a drobné stavebné odpady. Miestne dane sa stali fakultatívnym príjmom obce. Jediná daň, ktorá je v pôsobnosti vyššieho územného celku je daň z motorových vozidiel. 
Medzi miestne dane, ktoré sú v pôsobnosti obcí patria:

- daň z nehnutel'ností,

- daň za psa,

- daň za užívanie verejného priestranstva,

- daň za ubytovanie,

- daň za predajné automaty,

- daň za nevýherné hracie prístroje,

- daň za vjazd a zotrvanie motorového vozidla v historickej časti mesta,

- dan̆ za jadrové zariadenie.

Úlohy, ktoré vyššie územné celky a obce vykonávajú v prenesenom výkone zo štátnej správy sú aj nad’alej financované štátnymi dotáciami zo štátneho rozpočtu a nie sú predmetom fiškálnej decentralizácie. Kompetencie, ktoré sú prenesené zo štátnej právomoci na obce či vyššie územné celky pojednáva zákon NR SR č. 416/2001 Z.z. o prechode niektorých pôsobností z orgánov štátnej správy na obce a na vyššie územné celky.

V súlade s platným a v tom čase novovzniknutým zákonom č. 416/2001 Z.z o prechode niektorých pôsobností štátnej správy na obce a vyššie územné celky bolo postupne v piatich etapách presunutých viac 400 kompetencií, všeobecne a prakticky zo všetkých častiach verejnej správy. Presuny právomocí sa uskutočnili postupne: k 1.1. 2002, k 1.4. 2002, k 1.7. 2002, k 1.1. 2003 a k 1.1. 2004. Prechod týchto kompetencií boli sprevádzané mnohými nedostatkami a preto vláda Slovenskej republiky v júni 2004 prijala osobitné uznesenie na odstránenie týchto nedostatkov, avšak ministerstvá ho plnilo len po formálnej stránke.

Tabul'ka 3: Prenesené pôsobnosti štátnej správy

\begin{tabular}{|c|c|c|}
\hline & Obec & Vyšší územný celok \\
\hline $\begin{array}{l}\text { Prenesené pôsobnosti štátnej } \\
\text { správy }\end{array}$ & $\begin{array}{l}\text { - oblast' matrík, stavebného } \\
\text { poriadku a čast' úloh týkajúce } \\
\text { sa školstva. Tieto úlohy obce } \\
\text { vykonávajú v mene štátu a štát } \\
\text { je zodpovedný za riadne } \\
\text { plnenie, riadenie a kvalitu } \\
\text { služieb a financovanie týchto } \\
\text { úloh. }\end{array}$ & $\begin{array}{l}\text { - oblast' riadenia v školstve, } \\
\text { zdravotníctve, cestnej doprave, } \\
\text { civilnej ochrany, sociálnej } \\
\text { pomoci, územného plánovania, } \\
\text { telesnej kultúry, divadelnej } \\
\text { činnosti, múzeí a galérií, } \\
\text { knižníc, humánnej farmácie, } \\
\text { regionálneho } \\
\text { a cestovného ruchu. }\end{array}$ \\
\hline
\end{tabular}

Zdroj: vlastné spracovanie zákona NR SR č. 416/2001 Z.z.

Príjmy obcí a vyšších územných celkov po zavedení fiškálnej decentralizácie upravuje zákon NR SR č. 583/2004 Z.z. o rozpočtových pravidlách územnej samosprávy, ktorého zavedením šlo o posilnenie postavenia obcí a vyšších územných celkov a nastolenie nezávislosti vo vzt'ahu k procesom v štátnej správe. Zákon určil nasledovnú štruktúru príjmov pri rozdelení na vlastné a cudzie príjmy: 
Tabul'ka 4: Štruktúra príjmov

\begin{tabular}{|c|c|c|}
\hline & Príjmy do rozpočtu obce & $\begin{array}{l}\text { Príjmy do rozpočtu vyšších } \\
\text { územných celkov }\end{array}$ \\
\hline Vlastné príjmy & $\begin{array}{l}\text { - miestne dane a poplatky } \\
\text { nedaňové príjmy z vlastníctva } \\
\text { a z prevodu vlastníctva majetku } \\
\text { obce a z činnosti obce a jej } \\
\text { rozpočtových organizácií } \\
\text { - výnosy z finančných } \\
\text { prostriedkov obce } \\
\text { - sankcie za porušenie finančnej } \\
\text { disciplíny uložené obcou } \\
\text { dary a výnosy dobrovol'ných } \\
\text { zbierok v prospech obce }\end{array}$ & $\begin{array}{l}\text { - daň z motorových vozidiel (je } \\
\text { miestnou daňou, ale správcom } \\
\text { je VÚC) } \\
\text { - nedaňové príjmy z vlastníctva } \\
\text { majetku vyššieho územného } \\
\text { celku a z činnosti rozpočtových } \\
\text { organizácií v jeho správe } \\
\text { - výnosy z finančných } \\
\text { prostriedkov VÚC } \\
\text { - sankcie za porušenie finančnej } \\
\text { disciplíny uložené VÚC } \\
\text { - dary a výnosy dobrovol'ných } \\
\text { zbierok v prospech VÚC }\end{array}$ \\
\hline Cudzie príjmy & $\begin{array}{l}\text { - dotácie zo štátneho rozpočtu na } \\
\text { úhradu nákladov preneseného } \\
\text { výkonu štátnej správy a dotácie } \\
\text { zo štátnych fondov } \\
\text { - účelové dotácie z rozpočtu VÚC } \\
\text { alebo z rozpočtu inej obce } \\
\text { - prostriedky z Európskej únie }\end{array}$ & $\begin{array}{l}\text { - dotácie zo štátneho rozpočtu na } \\
\text { úhradu nákladov preneseného } \\
\text { výkonu štátnej správy a dotácie } \\
\text { zo štátnych fondov } \\
\text { - účelové dotácie z rozpočtu obce } \\
\text { alebo z rozpočtu iného VúC } \\
\text { - prostriedky z Európskej }\end{array}$ \\
\hline
\end{tabular}

Zdroj: vlastné spracovanie zákona NR SR č. 583/2004 Z.z.

\section{Zdanenie nehnutel'ností v Slovenskej republike v kontexte na Mesto Čadca}

Miestne dane a najmä najčastejšie skloňovaná daň z nehnutel'nosti prešla od svojho počiatku v modernej Slovenskej republike mnohými zásadnými zmenami či už z pohl'adu správcu dane alebo daňového subjektu. S nástupom fiškálnej decentralizácie na Slovensku sa daň z nehnutel'nosti stála významným faktorom pre zabezpečenie finančnej stability väčšiny samospráv. Spojením pojmov fiškálna decentralizácia a miestne dane vznikla stabilita, nezávislost' a zodpovednost' miestnych samospráv za svoje rozhodovanie. V daňovej sústave Slovenskej republiky patrí dani z nehnutel'nosti významné miesto a od roku 1993 vstúpil do platnosti nový zákon č. 317/1992 Z.z. o dani z nehnutel'ností (Nižňanský, 2009). Do roku 1993 platil zákon o dani z pozemkov, domovej dani a lokalizačný poplatok.

Právna úprava NR SR 317/1992 Z.z. o dani z nehnutel'ností pozostávala zo 6 častí, ktoré upravovali daň z pozemkov, daň zo stavieb, daň z bytov a ostatné ustanovenia zákona.

Principiálne, vecné a formálne nedostatky zákona boli nasledovné:

- Zdaňovanie podl'a rôznych princípov - niektoré pozemky sa zdaňovali pevnou sadzbou za $\mathrm{m}^{2}$, iné percentom podl'a hodnoty pozemku, existovalo zbytočne vel'a sadzieb

- Zákon obsahoval množstvo výnimiek, ktoré nemali opodstatnenie.

Zákon 317/1992 Z.z. bol osemkrát novelizovaný, najdôležitejšími novelizáciami boli zákony NR SR č. 87/1993 Z.z. kde bolo spresnené zabezpečenie správneho uplatňovania zákona v praxi, zákon NR SR č. 159/1993 Z.z., ktorého novelizácia priniesla zvýšenie dane z pozemkov a dane zo stavieb na rok 1993 o 25\%, zákon NR SR č. 317/1993 Z.z. priniesol posilnenie postavenia samospráv ako správcom dane z nehnutel'ností. Po všetkých ôsmych novelizáciách bol pripravený kvalitný základ pre vytvorenie nového zákona NR SR č. 582/2004 Z.z. o miestnych dania a miestnom poplatku za komunálne odpady a drobné stavebné odpady, ktorého súčast'ou je i čast' upravujúca daň z nehnutel'nosti. Prijatím tohto zákona do reálnej praxe znamenalo upevnenie finančnej samostatnosti samospráv a posilnenie finančnej decentralizácie $\mathrm{v}$ rámci systému Slovenskej republiky. Každá zmena v daňovom 
systéme ovplyvní správcov daní, ale i daňové subjekty. Práve daň z nehnutel'ností výrazne ovplyvnila sociálne, podnikatel'ské i politické prostredie a to $\mathrm{z}$ dôvodu samostatného rozhodovania samospráv pri určovaní sadzieb dane z nehnutel’nosti (Jakubíková 2008).

Obrázok 1 zachytáva vývoj priemerných sadzieb daní z nehnutel’ností naprieč rokmi 2004 2016 kde je relatívne dobre vidiet' kedy majú byt' komunálne vol'by v Slovenskej republike, pretože komunálne vol'by výrazným spôsobom ovplyvňujú daný vývoj sadzieb, na ktorý upozorňujú mnohí autori. Zväčša pred komunálnymi vol'bami sa sadzby daní upravujú smerom nadol pre zvýšenie opätovného zvolenia do čela obce, avšak po vol'bách sa sadzby daní zas zvyšujú.

Obrázok 1: Vývoj priemerných sadzieb daní z nehnutel’nosti v Slovenskej republike



Zdroj: Webový portál Podnikatel'skej aliancie Slovenska: Daň z nehnutel'ností [online][vid. 2.januára 2017]. Dostupné $\quad \mathrm{z}<\mathrm{http}$ ://alianciapas.sk/dane-z-nehnutelnosti-sa-menili-iba-v-niekolkych-mestach-najviac-navychode/>.

Mesto Čadca je okresným mestom a svojou polohou na medzinárodných trasách je tak výbornou lokalitou pre podnikanie. Čadca je hlavným železničným uzlom z Českej republiky alebo Pol'ska, taktiež aj cestnou dopravou patrí medzi významné tranzity.

Zdanenie nehnutel'ností v meste Čadca je neodmyslitel'nou súčast'ou pre obecný rozpočet a mesto každoročne očakáva toto inkaso. Finančné prostriedky využíva mesto na pokrytie svojich výdavkov či už v podobe miezd pre zamestnancov alebo v rámci investícií do mesta.

Tabul'ka 5 poukazuje na podiel dane v rozpočte na celkových príjmoch mesta. Ako je vidiet' podiel dane z nehnutel'ností na príjmoch mesta, je zrejmé, že tento podiel nie je príliš vel'ký, avšak predstavitelia obce každoročne na tieto finančné prostriedky čakajú a využívajú ich na pokrytie nákladov spojených s udržiavaním obce, pokrytie miezd zamestnancov. Predpis dane v roku 2008 bol znížený takmer o $300000 €$ oproti roku 2007 z dôvodu zvýšenia zákonných úl'av na daň z nehnutel'ností pre daňové subjekty.

Tabul'ka 5: Podiel daní v rozpočte mesta - celkových príjmoch

\begin{tabular}{|c|c|c|c|}
\hline Rok & $\begin{array}{c}\text { Príjmy rozpočtu } \\
\text { Mesta Čadca }\end{array}$ & $\begin{array}{c}\text { Predpis dane } \\
\text { z nehnutel'nosti }\end{array}$ & $\begin{array}{c}\text { Podiel dane z nehnutel'nosti } \\
\text { na príjmoch }\end{array}$ \\
\hline $\mathbf{2 0 0 6}$ & $10933944 €$ & $938430 €$ & $8,58 \%$ \\
\hline $\mathbf{2 0 0 7}$ & $11895804 €$ & $962687 €$ & $8,09 \%$ \\
\hline $\mathbf{2 0 0 8}$ & $15488050 €$ & $677487 €$ & $4,37 \%$ \\
\hline $\mathbf{2 0 0 9}$ & $21014233 €$ & $690434 €$ & $3,29 \%$ \\
\hline $\mathbf{2 0 1 0}$ & $18834644 €$ & $691731 €$ & $3,67 \%$ \\
\hline $\mathbf{2 0 1 1}$ & $14250027 €$ & $664517 €$ & $4,66 \%$ \\
\hline $\mathbf{2 0 1 2}$ & $14984572 €$ & $897890 €$ & $5,99 \%$ \\
\hline $\mathbf{2 0 1 3}$ & $13902787 €$ & $968513 €$ & $6,97 \%$ \\
\hline $\mathbf{2 0 1 4}$ & $19909255 €$ & $985420 €$ & $4,95 \%$ \\
\hline $\mathbf{2 0 1 5}$ & $14840229 €$ & $989768 €$ & $6,67 \%$ \\
\hline
\end{tabular}

Zdroj: Webový portál Mesta Čadca: Záverečné účty [online][vid. 2.januára 2017]. Dostupné $\mathrm{z}<$ http://www.mestocadca.sk/samosprava-mesta/ekonomika-mesta.html>. 
Obrázok 2 zachytáva predpis dane z nehnutel'ností v sledovanom období, v každom jednom roku 2006 až 2015. V roku 2006 činil predpis $938430 €$ a v nasledujúcich 5 rokoch sa predpis dane znížil až o $28 \%$ v piatom roku a výška poklesu bola takmer $300000 €$ čo bolo vyvolané schválením zníženia alebo oslobodenia od platby dane z nehnutel'ností pre daňové subjekty, v reálnom príklade šlo o zvýšenie úl'avy z 30\% až na 50\% a dokonca v roku 2010 až na $60 \%$ úl'ava na platbu dane z nehnutel'ností. Ked’že už bolo neúnosné pre mesto poskytovat' úl'avu na daň vo výške $60 \%$, pre rok 2012 bolo mestským zastupitel'stvom schválené zníženie úl'avy zo $60 \%$ na $30 \%$ čím mesto inkasovalo do rozpočtu o viac ako $200000 €$, čo predstavovalo približne $26 \%$ nárast oproti roku 2011.

Obrázok 2: Predpis dane z nehnutel'ností v období 2006 - 2015

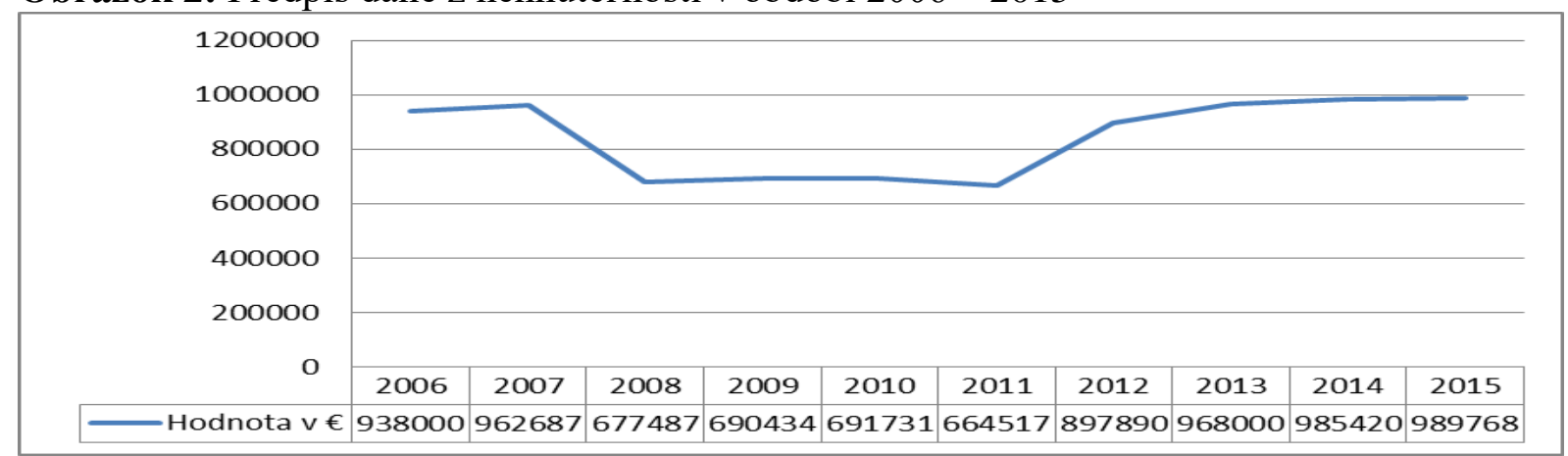

Zdroj: Webový portál Mesta Čadca: Záverečné účty [online][vid. 2.januára 2017]. Dostupné $\mathrm{z}<$ http://www.mestocadca.sk/samosprava-mesta/ekonomika-mesta.html>.

Z primárneho výskumu, ktorý bol vykonávaný na Mestskom úrade v Čadci, na vzorke 566 respondentov - daňových subjektov vlastniacich nejaký druh nehnutel'nosti v meste Čadca vyplynulo, že $18 \%$ respondentov si myslí, že výnos z dane z nehnutel'ností sa využíva na údržbu ciest a chodníkov v meste, $10 \%$ si myslí, že výnos je použitý na kosenie a údržbu zelene. Využitie výnosu z tejto dane na výstavbu a údržbu detských ihrísk odpovedalo $13 \%$ respondentov a na kultúrne podujatia len $8 \%$ respondentov. Viac ako polovica, 51\% respondentov si myslí, že výnos z tejto dane mesto nevyužíva ako investíciu pre rozvoj mesta a pre uspokojenie potrieb občanov.

Obrázok 3: Návratnost' výnosu z dane z nehnutel’nosti

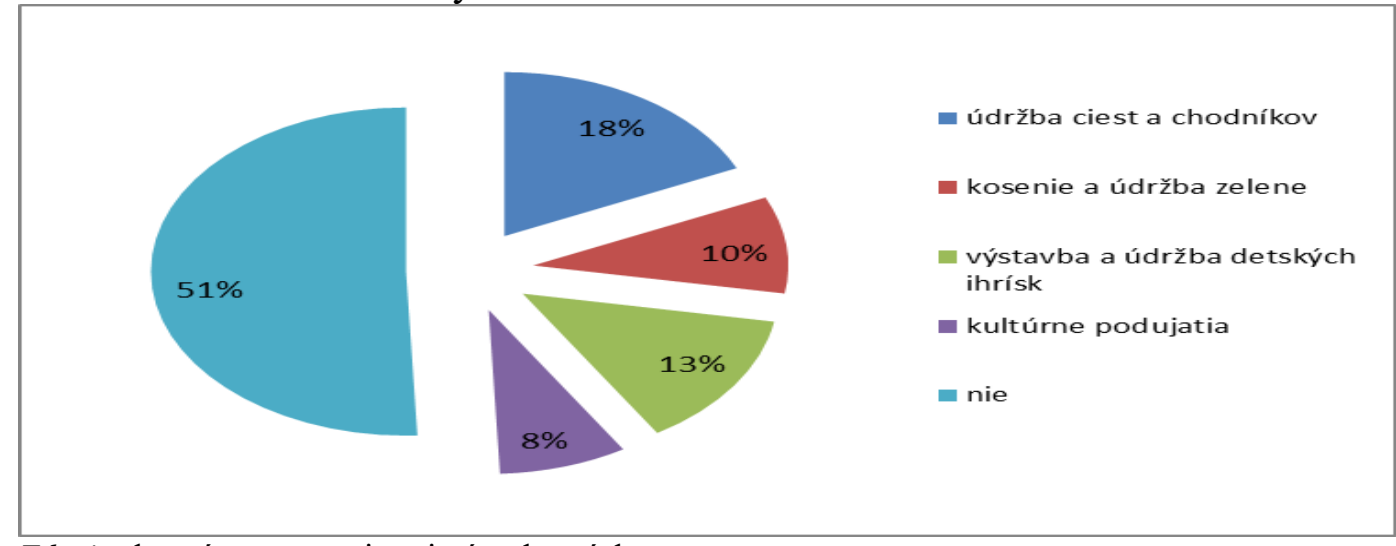

Zdroj: vlastné spracovanie primárneho výskumu 


\section{Záver}

Prechodom z fiškálnej centralizácie na fiškálnu decentralizáciu sa udiali vo verejnej správe, tj. $\mathrm{v}$ obciach i vyšších územných celkoch epochálne zmeny vodobe financovania, samostatnosti, rozhodovania, ale i kontrole nad finančnými prostriedkami, ktoré tieto subjekty mali pred fiškálnou decentralizáciou a následne po uskutočnení fiškálnej decentralizácie v Slovenskej republike.

Pred nástupom fiškálnej decentralizácie boli nižšie úrovne vlády silne finančne viazané a závislé od dotácií, ktoré im boli pridel'ované zo štátneho rozpočtu. Takmer všetky finančné prostriedky obce získavali prostredníctvom dotácií čím obce mali nízku finančnú autonómiu. Realizáciou druhej etapy fiškálnej decentralizácie mali nastat' radikálne zmeny v získavaní finančných prostriedkov do rozpočtov obcí prostredníctvom posilnenia daňových príjmov, posilnenie finančnej autonómie nižších úrovní vlády.

Sumarizáciou dostupných zdrojov, ich vyhodnotenia má za následok, že fiškálna decentralizácia $\mathrm{v}$ podmienkach Slovenskej republike prispela $\mathrm{k}$ posilneniu finančnej autonómie nižších úrovní vlády - obcí i vyšších územných celkov. Nie je možné nespomenút', že príjmy z výnosu podielovej dane vzrástli na základe rastu HDP v Slovenskej republike a taktiež prostredníctvom daňových reforiem, čím nižšie úrovne vlády môžu relatívne bez problémov plánovat' rozpočet v budúcom období.

Posilnením daňovej právomoci pri určovaní sadzieb pri dani z nehnutel'ností a ostatných miestnych daní sa preukázatel’ne zvýšili inkasá do rozpočtov nižších úrovní vlády. Avšak Slovenská republika je iba na začiatku čo sa týka dane z nehnutel'ností, pretože podiel dane $\mathrm{z}$ nehnutel'ností $\mathrm{v}$ rámci finančných zdrojov rozpočtu je stále len marginálnym príjmom aj ked' dôležitým pre obce v porovnaní s vyspelejšími krajinami. V podstate aj týmto spôsobom sa nižšie úrovne vlády stali ekonomicky efektívne, pretože disponujú pomerne dostatočných množstvom finančných prostriedkov, čím sa zabezpečuje dlhodobejšia finančná stabilita. Avšak stále nie je vyriešená otázka použitia výnosov z dane z nehnutel'ností, pretože predstavitelia obce nepoukazujú, ktoré finančné prostriedky boli na aký účel využité a tak občania obce nevidia potenciál tejto dane ako rozvojovej dane.

Ciel' fiškálnej decentralizácie sa relatívne podarilo splnit' a to zvýšenie finančnej autonómie nižších úrovní vlády, avšak je otázne ako sa bude vyvíjat' situácia týchto subjektov v dlhšom časovom horizonte v Slovenskej republike.

\section{Literatúra}

[1] BRYSON, P. J. and G. C. CORNIA, 2000. Fiscal decentralization in economic transformation: the Czech and Slovak cases, Europe-Asia Studies, 52(3), pp. 507-522. doi:10.1080/713663064.

[2] DABLA-NORIS, E., 2006. The Challenge od Fiscal Decentralisation in Transition Countries. Comparative Economic Studies [online]. 48(1), 100-131 [vid.17. decembra 2017]. ISSN 1748-3320.

Dostupné http://www.palgravejournals.com/ces/journal/v48/n1/full/8100063a-html.

[3] Council of Europe (1985) European charter of local self-government, Strasbourg.

[4] DZIOBEK, C., C. GOUIERREZ MANGAS and P. KUFA., 2011. Measuring Fiscal Decentralization - Exploring the IMF's Databases. IMF Working Paper [online]. 2011. 
30 s. [vid. 18. decembra 2016]. IMF Working Paper, no. WP/11/126. Dostupné z: http://www.imf.org/external/pubs/ft/wp/2011/wp11126.pdf.

[5] HOLLIS, G. and K. PLOKKER, 1995. Towards democratic decentralisation: transforming regional and local government in the new Europe, European Commission, Brussels.

[6] HORNE, R. and D. FELSENSTEIN, 2010. Is property assessment really essential for taxation? Evaluating the performance of an "Alternative Assessment" method. Land use policy 27(4), 1181-1189. ISSN 02648377.

[7] KNEŽOVÁ, J., 2015. Finančné zdroje obcí v Slovenskej republike v desat'ročnej reflexii fiškálnej decentralizácie. SOCIETAS ET IURISPRUDENTA, 3(3), 104-144. ISSN 13395467.

[8] KRIVÝ, V., 1996. Kryštalizácia základných politických zoskupení vo vzt’ahu k štiepeniam slovenskej spoločnosti. Sociológia, 20(2), 127-146. ISSN 1336-8613.

[9] NIŽŇANSKÝ, V. a M. HAMALOVÁ, 2013. Decentralizácia a Slovensko VŠEMVS, Bratislava. ISBN 978-80-89600-18-2.

[10] PORCELI, F., 2009. Fiscal Decentralisation and Efficiency of Government. A Brief Literature Rewies [online]. 2009. 12 s. [vid. 18. decembra 2016]. Dostupné z: http://www2.warwick.ac.uk/fac/soc/economics/staff/fporcelli/dec_efficiency_gov.pdf.

[11] PRESBITERO, A. F., A. SACCHI and A. ZAZZARO, 2014. Property tax and fiscal discipline in OECD countries, Economics Letters 124(3): 428-433. ISSN 01651765.

[12] RADVAN, M., 2007. Zdanění majetku v Evropě. 1th ed. Praha: C. H. Beck. ISBN 97880-7179-563-6.

[13] SWIANIEWICZ, P., 2003. Foundations of fiscal decentralization: benchmarking guide for countries in transition. Local Government and Public Service Reform Initiative, Budapest, Hungary. ISSN 14174855.

[14] WETZEL, D. and J. DUNN, 2001. Decentralization in transition economies: challenges and the road ahead. PREM Unit Europe and Central Asia, World Bank, Washington, DC, United States.

[15] Zákon NR SR č. 87/1993 Z.z. novela zákona SNR č.318/1992 Zb. o dani z dedičstva. Ministerstvo spravodlivosti Slovenskej republiky [online]. [vid. 2 januára 2017]. Dostupné z: https://www.slov-lex.sk/domov

[16] Zákon NR SR č. 159/1993 Z.z. novela zákona NR SR č.14/1993 Z.z. o štátnom rozpočte SR na r.1993. Ministerstvo spravodlivosti Slovenskej republiky [online]. [vid. 2 januára 2017]. Dostupné z: https://www.slov-lex.sk/domov

[17] Zákon NR SR č. 317/1992 Z.z o dani z nehnutel'nosti. Ministerstvo spravodlivosti Slovenskej republiky [online]. [vid. 2 januára 2017]. Dostupné z: https://www.slovlex.sk/domov

[18] Zákon NR SR č. 416/2004 Z.z. o prechode niektorých pôsobností z orgánov štátnej správy na obce a na vyššie územné celky. Ministerstvo spravodlivosti Slovenskej republiky [online]. [vid. 2 januára 2017]. Dostupné z: https://www.slov-lex.sk/domov

[19] Zákon NR SR č. 564/2004 Z.z. o rozpočtovom určení výnosu dane z príjmov územnej samospráve a o zmene a doplnení niektorých zákonov v znení neskorších predpisov. Ministerstvo spravodlivosti Slovenskej republiky [online]. [vid. 2 januára 2017]. Dostupné z: https://www.slov-lex.sk/domov 
[20] Zákon NR SR č. 582/2004 Z.z. o miestnych daniach a miestom poplatku za komunálne odpady a drobné stavebné odpady v znení neskorších predpisov. Ministerstvo spravodlivosti Slovenskej republiky [online]. [vid. 2 januára 2017]. Dostupné z: https://www.slov-lex.sk/domov

[21] Zákon NR SR č. 583/2004 Z.z. o rozpočtových pravidlách územnej samosprávy a o doplnení niektorých zákonov. Ministerstvo spravodlivosti Slovenskej republiky [online]. [vid. 2 januára 2017]. Dostupné z: https://www.slov-lex.sk/domov

[22] Zákon NR SR č. 668/2004 Z.z. o rozdel'ovaní výnosu dane z príjmov územnej samospráve. Ministerstvo spravodlivosti Slovenskej republiky [online]. [vid. 2 januára 2017]. Dostupné z: https://www.slov-lex.sk/domov 